\title{
Glycaemic, Lipidaemic and Antioxidant Profiles of Alloxan-Induced Diabetic Wistar Rats Treated with Glibenclamide and Aqueous Extract of Gongronema latifolium (Benth)
}

\author{
Patrick Emeka ABA
}

\author{
University of Nigeria, Nsukka, Department of Veterinary Physiology and Pharmacology, \\ EnuguState,Nigeria; patrick.aba@unn.edu.ng (corresponding author)
}

\begin{abstract}
The current study investigated the ameliorative effects of combined therapy of glibenclamide and G. latifolium (GL) on several biochemical parameters of alloxaized Wistar rats. Thirty adult male Wistar rats assigned into 5 groups of 6 rats each were used for the study. Groups 2-5 were intraperitoneally injected with $160 \mathrm{mg} / \mathrm{kg}$ of alloxan monohydrate and upon establishment of diabetes (Fasting Blood Glucose (FBG) $\geq 126 \mathrm{mg} / \mathrm{dl}$ ) were treated with $10 \mathrm{ml} / \mathrm{kg}$ distilled water (DW), 2 $\mathrm{mg} / \mathrm{kg}$ glibenclamide, $200 \mathrm{mg} / \mathrm{kg} \mathrm{GL}$ and $2 \mathrm{mg} / \mathrm{kg}$ glibenclamide and $200 \mathrm{mg} / \mathrm{kg} \mathrm{GL}$ respectively. Rats in group 1 were not made diabetic and served as normal control. All the treatments were realized through daily oral route using gastric tube, for 21 days. Results indicated that the treatment of diabetic rats with a combination of glibenclamide and GL significantly reduced the elevated glucose levels, cholesterol, triacylglycerol, low density lipoprotein and malondialdehyde levels, along with increases in the high density lipoprotein, glutathione values and catalase activities, when compared to diabetic untreated group. It was concluded that the combined therapy of glibenclamide and GL showed superior antihyperglycemic, hypolipidaemic and antioxidant effects compared to either of them used alone.
\end{abstract}

Keywords: antioxidants, glibenclamide, glycemia, Gongronema latifolium, lipid profile

\section{Introduction}

Diabetes mellitus is both a metabolic and an endocrine disease characterized essentially by elevated fasting blood glucose consequent upon the lack of insulin or insulin inaction (Akah et al., 2009). Type 1 diabetes mellitus, formerly insulin dependent diabetes mellitus (IDDM), is characterized by the lack of insulin, while type 2 , formerly known as non-insulin dependent diabetes mellitus, is characterized by insulin resistance by the cells (Lukic et al., 1991; Holt, 2004; Kaku, 2010). In both cases, there is elevated fasting blood glucose.

Insulin is a hormone implicated in the metabolism of carbohydrates. Insulin is secreted by the beta cells of the islet of langerhans and has a role in sensitizing the glucose transporters and receptors, with the ultimate role of reducing the circulating blood glucose (Khunti et al., 2013). The lack of insulin therefore leads to increased glucose in the blood.

The management of diabetes mellitus is targeted at achieving euglycaemia (normal fasting blood glucose value). This can be realized by multiple or combined treatment with various agents that have diverse mechanism of actions. For instance, insulin-secretion enhancement agents such as sulfonylurea (glibenclamide) may be combined with agents that reduce hepatic release of glucose into the circulation, such as biguanides (Metformin), to achieve desired anti-diabetic effect (Bennett et al., 2011). Combination therapy therefore is a hall mark of diabetes management (Bennett et al., 2011).

Glibenclamide, a sulfonylurea, is a known anti-diabetic agent which acts by stimulating the pancreatic beta cells to produce insulin (Bennett et al., 2003). Some pharmacological effects of insulin include hypoglycemia, increase in weight, reduction of low density lipoprotein and increases in high density lipoprotein (Bennett et al., 2003).

On the other hand, hypoglycaemic potential of Gongronema latifolium has been reported (Ugochukwu et al., 2003). G. latifofium, an herbaceous plant belonging to the family Asclepiadeceae is native of southern Nigeria and widely distributed across tropical Africa (Edet et al., 2011). It is used culinarily in Igbo land, south eastern Nigeria (Edet et al., 2011) and in traditional medicine in treatment of certain ailments. Several researched studies have also demonstrated the antihyperglycaemic activities of the plant extract (Sakihama $e t$ al., 2002; Aba and Okenwa-Ani, 2015). 
There is lack of information on the effect of combined therapy of glibenclamide and Gongronema latifolium (GL) on some biochemical parameters of alloxan-induced diabetic rat. This study is therefore aimed to investigate the effects of combining aqueous extract of GL and Glibenclamde on certain biochemical profiles of diabetic Wistar rats.

\section{Materials and Methods}

\section{The animals and the plant materials}

Adult male albino rats weighing between 150-200 g were obtained from the Department of Veterinary Medicine, University of Nigeria, Nsukka laboratory animal house. The rats were acclimatized for two weeks before the commencement of the experiment. During the acclimatization and in the course of the experiments, the rats were fed with Vital feed grower and clean drinking water was administrated ad libitum. The rats were housed in a stainless wire mesh cage. The experimental protocol used in this study was approved by the Ethics Committee of the University of Nigeria, Nsukka and conforms with guide to the care and use of animals in research and teaching of University of Nigeria, Nsukka, Enugu state, Nigeria.

The leaves of Gongronema latifolium were purchased from Ogige Market, Nsukka, Enugu state, Nigeria and identified by a botanist in Botany department, University of Nigeria, Nsukka, Enugu state, Nigeria. The voucher specimen was deposited in the herbarium section of the department.

\section{Chemicals, reagents, drugs}

Cholesterol, triacylglycerol and high density lipoprotein assay kits were provided from Randox, UK; Malondialdehyde, Catalase, Glutathione reagents from Sigma Aldrich, UK; Glibenclamide from Hovid, China; glucose strip and glucometer from Accu-Chek Active.

\section{The preparation of the plant extract}

Cold maceration method of extraction was employed. The leaves of $G$. latifolium were air dried at a very low intensity of sunlight to avoid denaturation of the active ingredients. They were pulverized and stored in air tight container pending its usage. About $2 \mathrm{~kg}$ of the pulverized plant material were soaked in $10 \mathrm{l}$ of distilled water with intermittent shaking every $2 \mathrm{~h}$ for $48 \mathrm{~h}$. The mixtures were filtered using Whatmann No. 1 filter paper and concentrated using oven adjusted to $37^{\circ} \mathrm{C}$.

\section{The induction of experimental diabetes}

The method of Venugopal et al. (1998) was used. Induction was done by single intraperitoneal injection of 160 $\mathrm{mg} / \mathrm{kg}$ of alloxan monohydrate after overnight fasting. The fasting blood glucose values were determined prior to induction. Thereafter, rats with fasting blood glucose levels of $126 \mathrm{mg} / \mathrm{dl}$ or above were considered diabetic.

\section{The experimental design}

Thirty adult male Wistar rats weighing between $150-200 \mathrm{~g}$ were assigned into 5 groups of 6 rats per group. Upon the establishment of diabetes, the rats were treated as summarized in Table 1 below.

Treatments were done daily for 21 days through the oral route using gastric tube. Fasting blood glucose values were assessed 1 h, 3 h, 6 h, 24 h, 7 days, 14 days and 21 days post treatment. Blood sample for lipid profile and in vivo antioxidant determinations were collected on days 7, 14 and 21 post treatment.

\section{The bloodsample collection}

The method of Parasuraman (2001) was used. Nonheparinized capillary tube was inserted into the capillary plexus in the medial canthus of the eye of the rats and blood was allowed to flow into sample bottles. The blood was kept in slant position and allowed to clot before serum was decanted into a clean bijou bottle for the biochemical analyses.

\section{Determination of serum cholesterol}

The serum cholesterol was determined by cholesterol oxidase-perioxidase method (Allain et al., 1974), for the invitro determination of cholesterol in serum or plasma, using cholesterol test kit. The serum sample $(0.01 \mathrm{ml})$ was reacted with $1.0 \mathrm{ml}$ of cholesterol working reagent containing cholesterol esterase, oxidase and peroxidase to form a coloured quinolic derivative. It was mixed properly and allowed to stand at room temperature for $10 \mathrm{~min}$. The standard was also prepared by adding $1.0 \mathrm{ml}$ of cholesterol working reagent and $0.01 \mathrm{ml}$ of standard. The absorbance of both the sample and standard were read against the working reagent blank at 500 $\mathrm{nm}$ within $60 \mathrm{~min}$ with a digital spectrophotometer.

The cholesterol concentration in each sample was obtained with the formula:

$\left(\frac{\text { Absorbance of sample }}{\text { Absorbance of standard }}\right) \times 206^{\circ}=$ Cholesterol concentratior

\section{HDL-Cholesterol}

Low density lipoproteins (LDL), very low density lipoproteins (VLDL) and chylomicrons fractions are precipitated quantitatively by the addition of phosphotungstic acid in the presence of magnesium ions. After centrifugation, the cholesterol concentration in the HDL fraction which remains in the supernatant was determined. Five hundred microliter of diluted R1 (phosphotungstic acid and magnesium chloride) were mixed with $200 \mu \mathrm{L}$ of serum sample or standard and allowed to sit for $10 \mathrm{~min}$ at room temperature. Thereafter, the clear supernatant was separated off within $2 \mathrm{~h}$ and the cholesterol content was determined by the CHOP-PAP method (Allain et al., 1974).

\section{Determination of cholesterol using the supernatant}

One hundred microliter $(100 \mu \mathrm{L})$ of supernatant (or standard or distilled water for blank as the case may be) were mixed with $1,000 \mu \mathrm{L}$ of reagent, mixed and incubated for 10 min at room temperature.

Table 1. Treatments of experimental rats with drug, plant extract and distilled water

\begin{tabular}{ll}
\hline Group & \multicolumn{1}{c}{ Treatment } \\
\hline 1 & Non-diabetic Wistar rats treated with $10 \mathrm{ml} / \mathrm{kg}$ distilled water (DW) \\
2 & Diabetic Wistar rats treated with $10 \mathrm{ml} / \mathrm{kg} \mathrm{DW}$ \\
3 & Diabetic Wistar rats treated with $2 \mathrm{mg} / \mathrm{kg} \mathrm{Glibenclamide}$ \\
4 & $\begin{array}{c}\text { Diabetic Wistar rats treated with } 2 \mathrm{mg} / \mathrm{kg} \mathrm{Glibenclamide} \mathrm{and} 200 \\
\mathrm{mg} / \mathrm{kg} \text { Gongronema.latifolium }\end{array}$ \\
5 & Diabetic Wistar rats treated with $200 \mathrm{mg} / \mathrm{kg}$ Gongronema.latifolium \\
\hline
\end{tabular}


410

Absorbance of the sample (Asample) and standard (Astandard) were measured against the reagent blank within $60 \mathrm{~min}$ (Friedwald et al., 1972) and the calculations were as follow:

$$
\begin{aligned}
& H D L \text { Cholesterol }(\mathrm{mg} / \mathrm{dl})=\frac{\text { Change Asample }}{\text { Change Astandard }} \times \text { Concentration of standard } \\
& L D L \text { Cholesterol }\left(\frac{\mathrm{mg}}{\mathrm{dl}}\right)=\text { Total cholesterol }-\left(\frac{\text { Triglyceride }}{5}\right)-H D L C h o l e s t e r o l \\
& V L D L \text { Cholesterol }(\mathrm{mg} / \mathrm{dl})=\frac{\text { Triglyceride }}{5}
\end{aligned}
$$

\section{Triacylglycerol}

Triacylglycerol measurement was done according to Allain et al. (1974). Triacylglycerol measurement is used in the diagnosis and treatment of diseases involving lipid metabolism and the serum sample or standard $(10 \mu \mathrm{L})$ was mixed with $1,000 \mu \mathrm{L}$ of buffer and enzyme reagent $\mathrm{R} 1$, and then incubated for $10 \mathrm{~min}$ at room temperature.

The absorbance of the sample (Asample) and standard (Astandard) were read against the blank $(1,000 \mu \mathrm{L}$ of $\mathrm{R} 1)$ at wavelength $500 \mathrm{~nm}$.

Triglyceride conc. $(\mathrm{mg} / \mathrm{dl})=\frac{\text { Asample }}{\text { Astandard }} \times \operatorname{standard~concentration}(191 \mathrm{mg} / \mathrm{dl})$

\section{Estimation of catalase}

The activity of catalase was assayed by the method of Sinha (1972). To $0.9 \mathrm{ml}$ of phosphate, $0.1 \mathrm{ml}$ of plasma and $0.4 \mathrm{ml}$ of $\mathrm{H}_{2} \mathrm{O}_{2}$ were added. The reaction was after $15,30,45$ and 60 seconds by adding $2 \mathrm{ml}$ of dichromate acetic acid mixture. The tubes were kept in a boiling water bath for $10 \mathrm{~min}$ and cooled. The colour developed was read at $530 \mathrm{~nm}$. Standards in the concentration range of 20-100 umoles was processed for the test. The activity of catalase was expressed as $\mathrm{U} / \mathrm{ml}$ for plasma (U- $\mu$ moles of $\mathrm{H}_{2} \mathrm{O}_{2}$ utilised / second).

Catalase activity $=\frac{\log _{B}^{A} \times 0.23}{0.00693}$, where $\mathrm{A}$ and $\mathrm{B}$ represent the range of the absorbance.

\section{Reduced glutathione}

The reduced glutathione level was determined by the method of Beutler et al. (1963). This method was based on the development of yellow colour when 5,5'- dithio-bis-2nitrobenzoic (DTNB) is added to a compound containing sulphydryl groups. The colour developed was read at $412 \mathrm{~nm}$ in a spectrophotometer.

About $0.2 \mathrm{ml}$ of sample was mixed with $1.8 \mathrm{ml}$ of EDTA solution. To this, $3.0 \mathrm{ml}$ of precipitating reagent were added, mixed thoroughly and kept for 5 min before centrifugation. To $2 \mathrm{ml}$ of the filtrate, $4 \mathrm{ml}$ of $0.3 \mathrm{M}$ disodium hydrogen phosphate solution and $1 \mathrm{ml}$ of DTNB reagent were added and the color developed was read at $412 \mathrm{~nm}$ in a spectrophotometer. A set of standard solutions containing 20$100 \mu \mathrm{g}$ of reduced glutathione was treated similarly. The values were expressed as $\mathrm{mg} / \mathrm{dl}$ for plasma. The enzyme activities were noted by dividing the absorbance with the slope of a standard curve (0.009).

\section{Estimation of lipidperoxidation (malondialdehyde)}

Lipid peroxidation was estimated by measuring spectrophotometrically the level of the lipid peroxidation product, malondialdehyde (MDA) as described by Wallin et al. (1993). A volume of $0.1 \mathrm{ml}$ of the serum was mixed with $0.9 \mathrm{ml}$ of $\mathrm{H}_{2} \mathrm{O}$ in a test tube. A volume of $0.5 \mathrm{ml}$ of $25 \%$ TCA (trichloroacetic acid) and $0.5 \mathrm{ml}$ of 1\% TBA (thiobarbituric acid) in $0.3 \% \mathrm{NaOH}$ were also added to the mixture. The mixture was boiled for $40 \mathrm{~min}$ in a water-bath and then cooled in cold water. Then $0.1 \mathrm{ml}$ of $20 \%$ sodium dodecyl sulfate (SDS) was added to the cooled solution and mixed properly. The absorbance was taken at $532 \mathrm{~nm}$ and $600 \mathrm{~nm}$ against a blank.

$$
\% \text { TBARS }=\frac{A_{532}-A_{600} \times 100}{0.5271 \times 0.1}(\mathrm{mg} / \mathrm{dl}) \text {, where } \mathrm{A} \text { is the }
$$
absorbance.

\section{Statistical analyses}

The data were analysed with One Way Analysis of Variance (ANOVA) using SPSS version 20. P values less than or equal to 0.05 were accepted as significant. The results were presented in tables as means ( \pm standard error of mean).

\section{Results}

Fasting Blood Glucose (FBG) levels of alloxan-induced diabetic rats treated with combination of glibenclamide and aqueous extract of $G$. latifolium

The pre-induction FBG of all the rats in groups 1-5 were statistically the same. Post-induction, the FBG value of rats in group 1 was significantly lower compared to other rat groups. One hour post treatment (PT), the FBG levels of rats in groups 3 and 4 were lower than those of group 2, but higher than those of group 1. Three hours following treatment, the FBG levels of rats in groups 1 and 4 were significantly lower than those of groups 2, 3 and 5. This persisted till the 6 hour. However, $24 \mathrm{~h}$ PT, the glucose levels of rats in groups 1, 3 and 4 were comparable until 14 days PT. Twenty one days PT, the FBG value of group 4 rats was lower than those of the normal control rats (group 1). Those treated with glibenclamide (group 3 rats) have their glucose levels comparable with that of the normal control group, while the FBG level of group 2 rats remained very high (Table 2).

\section{Total mean of cholesterol values}

On days 7 and 14 PT, the total mean of total cholesterol values of rats in groups 1 and 4 were statistically comparable ( $p$ $>0.05)$, but significantly $(\mathrm{p}<0.05)$ lower, than those of groups 2 and 3. On day $21 \mathrm{PT}$, the mean cholesterol value of rats in group 4 was significantly $(p<0.05)$ lower than that of the rats in group 1 . The total mean of cholesterol level of rats in group 3 was good comparing with that of groups 1,4 and 5 (Table 2).

\section{The mean of triacylglycerol values}

The mean of triacylglycerol (TAG) level of rats in group 4 was statistically the same $(p>0.05)$ as those of groups 3 and 5 rats on day 7 PT, but was significantly $(\mathrm{p}<0.05)$ lower than that of the group 2 rats. Rats in group 1 had lower TAG value compared to all other groups on this day. On day 14 PT, the TAG values of rats in groups 3 and 4 were similar and higher than that of the group 1 rats and lower than that of the group 2 rats. On day 21 PT, the mean TAG levels of rats in groups 1, 3 and 4 were comparable among these groups and higher than those of the other groups under experiment (Table 4).

\section{The mean of high density lipoprotein-cholesterol values}

The mean of high density lipoprotein-cholesterol (HDL) levels of all the rats in all the groups were statistically similar on 
Table 2. Fasting Blood Glucose (FBG) values of alloxan induced diabetic rats treated with combinations of glibenclamide and aqueous extract of G. latifolium

\begin{tabular}{|c|c|c|c|c|c|c|c|c|c|}
\hline \multirow[b]{2}{*}{ Group } & \multicolumn{9}{|c|}{ Fasting blood glucose levels (mg/dl) } \\
\hline & $\begin{array}{c}\text { Pre- } \\
\text { induction }\end{array}$ & $\begin{array}{c}0 \mathrm{~h} \text { Post } \\
\text { induction }(\mathrm{PI})\end{array}$ & $1 \mathrm{~h}$ PI & 3 h PI & $6 \mathrm{~h}$ PI & $24 \mathrm{~h}$ PI & 7 days PI & 14 days PI & 21 days PI \\
\hline 1 & $\begin{array}{c}63.33 \pm \\
1.45^{\mathrm{a}}\end{array}$ & $\begin{array}{c}68.33 \pm \\
1.85^{\mathrm{a}}\end{array}$ & $\begin{array}{c}71.33 \pm \\
0.88^{\mathrm{b}}\end{array}$ & $\begin{array}{c}64.00 \pm \\
1.52^{\mathrm{a}}\end{array}$ & $\begin{array}{c}63.00 \pm \\
0.57^{\mathrm{a}}\end{array}$ & $\begin{array}{c}72.66 \pm \\
6.33^{\mathrm{a}}\end{array}$ & $\begin{array}{c}61.33 \pm \\
0.88^{\mathrm{a}}\end{array}$ & $\begin{array}{c}60.33 \pm \\
1.85^{\mathrm{a}}\end{array}$ & $\begin{array}{c}66.00 \pm \\
3.60^{\mathrm{b}}\end{array}$ \\
\hline 2 & $\begin{array}{c}63.00 \pm \\
3.51^{\mathrm{a}}\end{array}$ & $\begin{array}{c}261.66 \pm \\
22.42^{\mathrm{b}}\end{array}$ & $\begin{array}{c}242.00 \pm \\
19.46^{c}\end{array}$ & $\begin{array}{c}226.33 \pm \\
14.20^{c}\end{array}$ & $\begin{array}{c}220.67 \pm \\
9.83^{c}\end{array}$ & $\begin{array}{c}218.33 \pm \\
10.13^{c}\end{array}$ & $\begin{array}{c}213.33 \pm \\
18.50^{\mathrm{b}}\end{array}$ & $\begin{array}{c}208.33 \pm \\
10.92^{\mathrm{c}}\end{array}$ & $\begin{array}{c}210.00 \pm \\
7.93^{\mathrm{d}}\end{array}$ \\
\hline 3 & $\begin{array}{c}63.66 \pm \\
6.83^{\mathrm{a}}\end{array}$ & $\begin{array}{c}261.33 \pm \\
4.70^{\mathrm{b}}\end{array}$ & $\begin{array}{c}206.33 \pm \\
3.17^{b}\end{array}$ & $\begin{array}{c}143.33 \pm \\
25.20^{\mathrm{b}}\end{array}$ & $\begin{array}{c}108.66 \pm \\
7.68^{\mathrm{b}}\end{array}$ & $\begin{array}{c}78.66 \pm \\
14.37^{\mathrm{ab}}\end{array}$ & $\begin{array}{c}80.00 \pm \\
1.15^{\mathrm{a}}\end{array}$ & $\begin{array}{c}67.00 \pm \\
3.51^{\mathrm{a}}\end{array}$ & $\begin{array}{c}64.00 \pm \\
2.08^{\mathrm{b}}\end{array}$ \\
\hline 4 & $\begin{array}{c}61.33 \pm \\
3.48^{\mathrm{a}}\end{array}$ & $\begin{array}{c}258.66 \pm \\
2.33^{\mathrm{b}}\end{array}$ & $\begin{array}{c}192.00 \pm \\
4.72^{\mathrm{b}}\end{array}$ & $\begin{array}{c}102.20 \pm \\
1.15^{\mathrm{ab}}\end{array}$ & $\begin{array}{c}84.33 \pm \\
8.29^{\mathrm{a}}\end{array}$ & $\begin{array}{c}75.00 \pm \\
5.03^{\mathrm{ab}}\end{array}$ & $\begin{array}{c}80.00 \pm \\
0.00^{\mathrm{a}}\end{array}$ & $\begin{array}{c}60.33 \pm \\
0.88^{\mathrm{a}}\end{array}$ & $\begin{array}{c}46.66 \pm \\
2.18^{\mathrm{a}}\end{array}$ \\
\hline 5 & $\begin{array}{c}64.00 \pm \\
0.57^{\mathrm{a}}\end{array}$ & $\begin{array}{c}287.00 \pm \\
3.51^{\mathrm{b}}\end{array}$ & $\begin{array}{c}212.33 \pm \\
5.92^{\mathrm{bc}}\end{array}$ & $\begin{array}{c}210.66 \pm \\
5.20^{c}\end{array}$ & $\begin{array}{c}200.33 \pm \\
2.90^{c}\end{array}$ & $\begin{array}{c}102.66 \pm \\
1.45^{\mathrm{b}}\end{array}$ & $\begin{array}{c}80.00 \pm \\
0.00^{\mathrm{a}}\end{array}$ & $\begin{array}{c}100.00 \pm \\
0.57^{\mathrm{b}}\end{array}$ & $\begin{array}{c}93.86 \pm \\
5.94^{\mathrm{c}}\end{array}$ \\
\hline
\end{tabular}

Different superscript along the same column (across groups) indicate significant difference at $\mathrm{p}<0.05$

Table 3. The total mean of cholesterol values of alloxan induced diabetic rats treated with combinations of glibenclamide and aqueous extract of $G$. latifolium

\begin{tabular}{lccc}
\hline & \multicolumn{3}{c}{ Total mean of cholesterol values $(\mathrm{mg} / \mathrm{dl})$ post treatment } \\
\hline Group & Day 7 & Day 14 & Day 21 \\
\hline 1 & $137.00 \pm 1.15^{\mathrm{a}}$ & $137.33 \pm 1.76^{\mathrm{a}}$ & $135.33 \pm 0.66^{\mathrm{b}}$ \\
2 & $152.66 \pm 2.84^{\mathrm{c}}$ & $178.66 \pm 0.65^{\mathrm{c}}$ & $200.33 \pm 0.88^{\mathrm{c}}$ \\
3 & $150.33 \pm 1.45^{\mathrm{c}}$ & $146.66 \pm 1.71^{\mathrm{b}}$ & $133.00 \pm 0.57^{\mathrm{a}}$ \\
4 & $142.33 \pm 1.85^{\mathrm{ab}}$ & $132.00 \pm 2.00^{\mathrm{a}}$ & $127.66 \pm 2.96^{\mathrm{a}}$ \\
5 & $145.20 \pm 1.67^{\mathrm{b}}$ & $148.33 \pm 2.33^{\mathrm{b}}$ & $137.33 \pm 2.90^{\mathrm{b}}$ \\
\hline $\begin{array}{l}\text { Different } \\
\text { significant differencence at } \mathrm{p}<0.05\end{array}$ & & &
\end{tabular}

day 7 PT. On day 14 PT, the mean HDL values of rats in groups 3 and 5 were not significantly different from each other, but were significantly higher than that of group 2 rats and lower than that of group 1 rats. On day $21 \mathrm{PT}$, the mean $\mathrm{HDL}$ levels of group 3 rats were similar to those of groups 1, 3, 4 and 5 , while that of group 2 rats were lower than all other groups (Table 5).

\section{The mean low density lipoprotein-cholesterol values}

The mean of low density lipoprotein (LDL) value of rats in group 1 was significantly $(\mathrm{p}<0.05)$ lower than those of the rats in all other rat groups on day 7. On day $14 \mathrm{PT}$, the mean LDL values of rats in groups 3 and 5 were statistically similar, but lower than that of the group 2 rats and higher than that of group 4 rats. On day $21 \mathrm{PT}$, the mean LDL values of rats in groups 1,3 and 4 were statistically the same and significantly lower than those of groups 2 and 5 (Table 6).

\section{The mean of very low density lipoprotein-cholesterol values}

The mean of very low density lipoprotein (VLDL) levels of rats in groups 3, 4 and 5 were statistically similar, significantly higher than that of the rats in group 1 and lower than that of the rats in group 2. On day 14 PT, the VLDL values of rats in group 5 were lower than that of the rats in group 2 and higher than those of the rats in groups 1, 3 and 4. On day 21 PT, the mean VLDL levels of rats in groups 1, 3, 4 and 5 were statistically similar and significantly lower than that of the group 2 rats (Table 7 ).

\section{The mean of malondialdehyde values}

The mean of malondialdehyde (MDA) levels of rats in groups 2, 3 and 4 were comparable on day 7 PT, but were higher than that of the group 1 rats and lower than that of
Table 4. The mean of yriacyglycerol values of alloxan induced diabetic rats treated with combinations of glibenclamide and aqueous extract of $G$. latifolium

\begin{tabular}{lccc}
\hline & \multicolumn{3}{c}{ Mean of Triacylglycerol values (mg/dl) post treatment } \\
\hline Group & Day 7 & Day 14 & Day 21 \\
\hline 1 & $150.33 \pm 0.33^{\mathrm{a}}$ & $155.00 \pm 2.51^{\mathrm{a}}$ & $152.00 \pm 1.00^{\mathrm{a}}$ \\
2 & $199.00 \pm 4.04^{\mathrm{d}}$ & $210.00 \pm 4.58^{\mathrm{d}}$ & $219.33 \pm 5.20^{\mathrm{c}}$ \\
3 & $167.33 \pm 1.20^{\mathrm{b}}$ & $166.66 \pm 1.76^{\mathrm{b}}$ & $158.33 \pm 5.36^{\mathrm{a}}$ \\
4 & $171.00 \pm 1.15^{\mathrm{bc}}$ & $173.33 \pm 1.85^{\mathrm{b}}$ & $151.66 \pm 1.45^{\mathrm{a}}$ \\
5 & $176.00 \pm 1.52^{\mathrm{c}}$ & $187.66 \pm 5.78^{\mathrm{c}}$ & $170.66 \pm 2.65^{\mathrm{b}}$ \\
\hline Different superscript along the same column (across groups) indicate
\end{tabular}
significant difference at $\mathrm{p}<0.05$

group 5 rats. On day $14 \mathrm{PT}$, the mean MDA values of groups 1 and 3 rats were similar and significantly lower compared to other rat groups. The mean MDA level of group 2 rats was significantly higher than those of the other groups. On day 21 $\mathrm{PT}$, the mean MDA values of groups 1, 3, 4 and 5 rats were comparable between each other, but were lower than that of group 2 rats (Table 8 ).

\section{The mean of reduced glutathione values}

The mean of reduced glutathione (GSH) values of the rats in groups $1,3,4$ and 5 were statistically similar and higher than that of group 2 rats on day 7 PT. On day 14 PT, the mean GSH values of rats in groups 1 and 3 were statistically similar to those of the rats in groups 4 and 5 , while the rats in group 2 remained lower than those of the other groups. On day 21 PT, the mean GSH level of rats in group 3 was similar to those of the rats in groups 1 and 4 . The mean GSH of the rats in group 2 was lower than those of the other groups (Table 9).

\section{The mean of catalase activities}

On day 7 PT, the mean of catalase activity of rats in group 2 was significantly lower than those of the other groups. On day $14 \mathrm{PT}$, the mean catalase activities of rats in groups 3 and 4 were statistically similar but higher than those exhibited by rats in groups 1,2 and 5. The mean catalase activities of rats in groups 1 and 5 were lower than that of the group 4 rats. Rats in group 2 had the lowest mean catalase activity (Table 10).

\section{Discussion}

This study investigated possible synergism of glibenclamide and Gongronema latifolium combination therapy on amelioration of diabetes and diabetes-associated biochemical parameters of alloxan-induced diabetic rats. 
412

Table 5. The mean of high density lipoprotein-cholesterol values of alloxan induced diabetic rats treated with combinations of glibenclamide and aqueous extract of $G$. latifolium

\begin{tabular}{|c|c|c|c|}
\hline \multirow[b]{2}{*}{ Group } & \multicolumn{3}{|c|}{$\begin{array}{l}\text { Mean of high density lipoprotein-cholesterol values (mg/dl) } \\
\text { post treatment }\end{array}$} \\
\hline & Day 7 & Day 14 & Day 21 \\
\hline 1 & $54.66 \pm 2.84^{a}$ & $57.66 \pm 0.66^{c}$ & $58.00 \pm 0.57^{b c}$ \\
\hline 2 & $48.66 \pm 0.88^{\mathrm{a}}$ & $31.33 \pm 1.85^{\mathrm{a}}$ & $26.66 \pm 0.88^{a}$ \\
\hline 3 & $32.33 \pm 1.20^{\mathrm{a}}$ & $50.00 \pm 0.57^{b}$ & $58.66 \pm 1.20^{\mathrm{bc}}$ \\
\hline 4 & $54.00 \pm 2.51^{a}$ & $59.00 \pm 0.57^{c}$ & $63.00 \pm 3.05^{c}$ \\
\hline 5 & $48.33 \pm 1.83^{\mathrm{a}}$ & $49.33 \pm 0.88^{b}$ & $53.33 \pm 1.76^{\mathrm{b}}$ \\
\hline
\end{tabular}

Table 7 . The mean of very low density lipoprotein-cholesterol values of alloxan induced diabetic rats treated with combinations of glibenclamide and aqueous extract of $G$. latifolium

\begin{tabular}{lccc}
\hline & \multicolumn{3}{c}{ Mean of very low density lipoprotein-cholesterol values } \\
$(\mathrm{mg} / \mathrm{dl})$ post treatment
\end{tabular}

Table 9. The mean of reduced glutathione values of alloxan induced diabetic rats treated with combinations of glibenclamide and aqueous extract of G. latifolium

\begin{tabular}{lccc}
\hline \multicolumn{4}{c}{ Mean of reduced glutathione values $(\mathrm{mg} / \mathrm{dl})$ post treatment } \\
\hline Group & Day 7 & Day 14 & Day 21 \\
\hline 1 & $164.66 \pm 2.40^{\mathrm{b}}$ & $165.00 \pm 2.88^{\mathrm{bc}}$ & $167.33 \pm 2.18^{\mathrm{c}}$ \\
2 & $121.66 \pm 1.75^{\mathrm{a}}$ & $115.66 \pm 2.33^{\mathrm{a}}$ & $106.66 \pm 3.33^{\mathrm{a}}$ \\
3 & $170.00 \pm 6.08^{\mathrm{b}}$ & $164.33 \pm 1.20^{\mathrm{bc}}$ & $171.66 \pm 3.17^{\mathrm{cd}}$ \\
4 & $165.33 \pm 3.20^{\mathrm{b}}$ & $168.66 \pm 0.88^{\mathrm{c}}$ & $182.66 \pm 2.18^{\mathrm{d}}$ \\
5 & $154.33 \pm 7.30^{\mathrm{b}}$ & $153.00 \pm 9.07^{\mathrm{b}}$ & $150.00 \pm 6.08^{\mathrm{b}}$ \\
\hline $\begin{array}{l}\text { Different } \\
\text { significant difference at } \mathrm{p}<0.05\end{array}$ & & &
\end{tabular}

Results of the fasting blood glucose values showed that $48 \mathrm{~h}$ post alloxan monohydrate injection there were significant increases in the FBG of groups 2-5 rats (induced groups) compared to that of the group 1 rats (normal control) (Table 2). This was attributed to the effect of alloxan monohydrate on pancreatic beta cells. Alloxan monohydrate is a chemical (analogous to glucose) that has been incriminated in destruction of pancreatic beta cells (Szukuldeski, 2001). This destruction is mediated by free radicals generated by series of redox reactions of alloxan monohydrate and dialuric acid (Munday, 1988). The sequela of this destruction of the pancreatic beta cells is a reduction in the level of circulating plasma insulin with attendant hyperglycaemia (Lachin and Reza, 1991).

Upon treatment of the diabetic rats with glibenclamide or G. latifolium extracts alone or in combination, the FBG of groups 3-5 rats (diabetic and treated groups) was reduced significantly $(\mathrm{p}<0.05)$ across the treatment periods (Table 2$)$. These reductions in the FBG values of the treated groups were attributed to the effect of the drug (glibenclamide) or the extract. Glibenclamide, a second generation sulfonylurea, is an anti-diabetic drug used in lowering elevated glucose levels (Bennett et al., 2011). G. latifolium, an herbaceous plant used
Table 6. The mean of low density lipoprotein-cholesterol values of alloxan induced diabetic rats treated with combinations of glibenclamide and aqueous extract of $G$. latifolium

\begin{tabular}{|c|c|c|c|}
\hline \multirow[b]{2}{*}{ Group } & \multicolumn{3}{|c|}{$\begin{array}{l}\text { Mean low density lipoprotein-cholesterol values }(\mathrm{mg} / \mathrm{dl}) \text { post } \\
\text { treatment }\end{array}$} \\
\hline & Day 7 & Day 14 & Day 21 \\
\hline 1 & $45.06 \pm 5.61^{\mathrm{a}}$ & $46.93 \pm 3.76^{a}$ & $45.73 \pm 3.14^{a}$ \\
\hline 2 & $58.33 \pm 4.79^{b}$ & $100.60 \pm 1.13^{c}$ & $126.46 \pm 3.58^{c}$ \\
\hline 3 & $65.00 \pm 1.44^{\mathrm{b}}$ & $63.73 \pm 2.04^{\mathrm{b}}$ & $43.53 \pm 1.26^{\mathrm{a}}$ \\
\hline 4 & $56.33 \pm 2.37^{b}$ & $45.76 \pm 5.21^{\mathrm{a}}$ & $40.80 \pm 1.74^{a}$ \\
\hline 5 & $62.26 \pm 1.33^{b}$ & $61.06 \pm 2.69^{b}$ & $63.13 \pm 6.38^{b}$ \\
\hline
\end{tabular}

Table 8. The mean of malondialdehyde values of alloxan induced diabetic rats treated with combinations of glibenclamide and aqueous extract of G. latifolium

\begin{tabular}{lccc}
\hline & \multicolumn{3}{c}{ Mean of malondialdehyde levels $(\mathrm{mg} / \mathrm{dl})$} \\
post treatment
\end{tabular}

Table 10. The mean of catalase activities of alloxan induced diabetic rats treated with combinations of glibenclamide and aqueous extract of $G$. latifolium

\begin{tabular}{lccc}
\hline \multicolumn{4}{c}{ Mean of catalase activities (IU/L) post treatment } \\
\hline Group & Day 7 & Day 14 & Day 21 \\
\hline 1 & $5.57 \pm 0.336^{\mathrm{b}}$ & $5.18 \pm 0.14^{\mathrm{b}}$ & $5.79 \pm 0.06^{\mathrm{b}}$ \\
2 & $2.66 \pm 0.16^{\mathrm{a}}$ & $2.10 \pm 0.06^{\mathrm{a}}$ & $1.19 \pm 1.15^{\mathrm{a}}$ \\
3 & $5.56 \pm 0.29^{\mathrm{b}}$ & $6.23 \pm 0.16^{\mathrm{c}}$ & $6.08 \pm 0.25^{\mathrm{bc}}$ \\
4 & $5.91 \pm 0.05^{\mathrm{b}}$ & $6.12 \pm 0.15^{\mathrm{c}}$ & $6.59 \pm 0.20^{\mathrm{c}}$ \\
5 & $5.77 \pm 0.33^{\mathrm{b}}$ & $4.96 \pm 0.11^{\mathrm{b}}$ & $5.38 \pm 0.31^{\mathrm{b}}$ \\
\hline Different & superscript along the same column (across groups) indicate
\end{tabular}
significant difference at $\mathrm{p}<0.05$

culinarily, has been reported to possess antihyperglycaemic properties (Ugochukwu et al., 2003).

The earlier significant $(\mathrm{p}<0.05)$ reductions in the FBG observed in the group (Group 4) treated with the combination (glibenclamide and $G$. latifolium) compared to the other treatment groups (Table 2) is an indication of synergistic hypoglycaemic actions of the two agents. Synergistic hypoglycaemic actions of $G$. latifolium with other agents have been earlier reported (Aba and Okenwa-Ani, 2015). The observation of severe hypoglycaemia in the group treated with the combination after 21 days is a pointer that subchronic treatment with the two agents might pose hypoglycaemic treat to diabetics at the tested doses. The hypoglycaemic episode is one of the leading side effects of anti-diabetic treatment (Ono 2008; Bennett et al., 2011).

The increases in the serum levels of total cholesterol, triacylglycerol, low density lipoprotein, very low density lipoprotein and decrease in high density lipoprotein levels were observed in diabetic untreated rats (Tables 3-7).

Diabetic dyslipidaemia is a well-known condition in diabetes mellitus (Thomas and Rampersad, 2004; Ozougwu et al., 2013). The decreases in the elevated total cholesterol, triacylglycerol, low density lipoprotein, very low density 
lipoprotein and increase in high density lipoprotein following treatments with glibenclamide and or $G$. latifolium suggest possible hypolipidaemic potentials of these agents. Several studies had also shown hypolipidaemic actions of glibenclamide (Bennett et al., 2011) and G. latifolium (Ugochukwu et al., 2013) when used alone. Much earlier significant ameliorative effects on dyslipidaemia were observed in the group treated with the combination of glibenclamide and $G$. latifolium, thus indicating synergism of the two agents in mitigating diabetic dyslipidaemia.

The results of oxidative stress markers indicated that following diabetes induction, the level of reduced glutathione and activity of catalase reduced significantly with appreciable increase in the level of malondialdehyde (Tables 8-10). Similar changes in the oxidative stress marker parameters in diabetic conditions had earlier been reported (Aba et al., 2015). During oxidative stress, the plasma levels of malondialdehyde increases with reductions in the levels and activities of antioxidant parameters. All treatment groups showed evidence of amelioration of these diabetes-induced oxidative stresses. Groups treated with combination of glibenclamide and $G$. latifolium particularly showed remarkable decreases in the MDA levels, increases in glutathione values and catalase activities 21 days PT. This result is in agreement with the reports of Aba and Okenwa-Ani (2015) who noted the ameliorative effects of either the glibenclamide or the $G$ .latifolium on oxidative stress markers.

\section{Conclusions}

Treatment of diabetic rats with combination of glibenclamide and $G$. latifolium reduced the elevated blood cholesterol, triacyglycerol, low density lipoprotein and very low density lipoprotein with an improvement on the level of high density lipoprotein 21 days post treatment. Further studies on dose-response tests should be carried on $G$. latifolium to determine the appropriate dose to be combined with glibenclamide to achieve the desired effects.

\section{References}

Aba PE, Okenwa-AniCP (2015). Biochemical effects of methanolic extracts of Vernonia amygdalina and Gongronema latifolium on alloxan-induced diabetic rats. British Journal of Pharmaceutical Research 9(2):1-10.

Aba PE, Igwebuike DC, Onah JA (2015). Effects of various concentrations of quail egg solution on gycemia and antioxidant parameters of alloxaninduced diabetic rats. Journal of Advanced Medical and Pharmaceutical Sciences 5(4):1-7.

Akah JA, Lemiji JA, Salawa OA, Okoye TC, Offiah NV (2009). Effects of Vernonia amygdalina on biochemical and haematological parameters in diabetic rats. Asian Journal of Medical Science 1(3):108-113.

Allain CC, Poon LS, Chan CS, Richmond W, Fu PU (1974). Enzymatic determination of total cholesterol. Clinical Chemistry 20:470-475.

Bennett WL, Maruthur NM, Singh S, Segal JB, Wilson LM, Chatterjee R, Marinopoulos SS, PuhanMA, Ranasinghe P, Block L, Nicholson WK, Hutfless S, Bass EB, Bolen S (2011). Comparative effectiveness and safety of medication for type 2 diabetes: An update including new drugs and 2-drug combinations. Annals of Internal Medicine 154(9):602613.
Beutler E, Duron O, Kelly BM (1963). Improved method for determination of blood glutathione. Journal of Laboratory and Clinical Medicine 61:882-888.

Edet EE, Atangwho IJ, Akpanabia MI, Edet TE, Uboh FE, David-Oku E (2011). Effect of Gongronema latifolium leaf extract on some liver enzymes and protein levels in diabetic and non-diabetic rats. Journal of Pharmaceutical and Biomedical Sciences 15:104-107.

Friedwald WT, Levy RL, Fredickson DS (1972). Estimation of low density lipoprotein cholesterol in plasma without use of the preparative ultracentrifuge. Clinical Chemistry 18:499-502.

Holt GI (2004). Diagnosis, epidemiology and pathogenesis of diabetes mellitus:an update for psychiatrics. British Journal of Psychiatry 184:5563.

Kaku K (2010). Pathophysiology of type 2 diabetes and its treatment policy. Japan Medical Association Journal 53(1): 41-46.

Khunti K, Davies MJ (2013). Diabetes prevention: NICE opportunity for implementing programs in the real world setting. Diabetic Medicine 30 (1):1-2.

Lachin T, Reza H (2012). Antidiabetic effect of cherries in alloxan-induced rats. Recent Patents on Endocrine Metabolic and Immune Drug Discovery 6:67-72.

Lukic ML, Stosic-Grujicic S, Ostojic N, Chan WL, Liew FY (1991). Inhibition of nitric oxide generation affects the induction of diabetes by streptozotocin in mice. Biochemical and Biophysical Research Communications 178:913-920.

Munday R(1988). Dialuric acid autoxidation. Effects of transition metals on the reaction rate and on the generation of reactive oxygen species. Biochemical Pharmacology 37:409-413.

Ono Y (2008). Diet therapy for diabetes and obesity, considering osteoporosis. Clinical Calcium 18:662-669.

Parasuraman S, Raveendran R, Kesavan R (2010). Blood sample collection in small laboratory animals. Journal of Pharmacology and Pharmacotherapy 1(2):87-93.

Sakihama Y, Cohen MF, Stephen C, Yamasaki GH (2002). Plant phenolic antioxidant and prooxidant activities: phenolics-induced oxidative damage mediated by metals in plant Toxicology 177:67-80.

Sinha AK (1972). Colorimetric assay of catalase. Analytical Biochemistry 47(2):389-394.

Thomas S, Rampersad M (2004). Anaemia in diabetes. Acta Diabetologica 41:13-17.

Ugochukwu NH, Babady NE, Coboure M, Gasset SR (2003). The effect Gongronema latifolium extract on serum lipid profile and oxidative stress in hepatocytes of diabetic rats. Journal of Biosciences 28(1):1-5.

Venogopal PM, Prince PSM, Pari L (1998). Hypogycemic activities of Syzigium cumini seeds effect on lipid peroxidation in alloxan diabetic rats. Journal of Ethnopharmacology 61:1-7.

Wallin B, Rosengren B, Shertyer HG, Camejo G (1993). Lipoprotein oxidation and measurement of thiobarbituric acid reacting substances formation in a single microfilter plate; its use for evaluation of antioxidants. Analytical Biochemistry 288:10-15. 